\title{
ANALISIS CUACA PADA SAAT PELAKSANAAN PENYEMAIAN AWAN DI WADUK PLTA KOTA PANJANG BULAN APRIL - MEI 2013
}

\author{
Erwin Mulyana \\ UPT HB BPPT
}

\begin{abstract}
ABSTRAK
Telah dilakukan analisis cuaca selama pelaksanaan TMC pada bulan April dan Mei 2013 di Waduk PLTA Kota Panjang. Temperatur permukaan laut di daerah Nino 3.4 menunjukkan ENSO netral dengan temperatur rata-rata pada bulan April dan Mei 2013 antara 27.6 s.d $27.7^{\circ} \mathrm{C}$ serta nilai anomaly antara -0.03 s.d $-0.1{ }^{\circ} \mathrm{C}$. Penjalaran MJO aktif yang menunjukkan terjadinya peningkatan aktifitas konvektif di wilayah Sumatra terjadi pada awal April dan akhir Mei 2013. Arah angin pada level gradient bertiup dari barat daya - barat laut dengan kecepaan 5-15 knot. Siklon Tropis Mahasen di utara Sumatera yang terjadi pada pertengahan bulan Mei berpengaruh terhadap berkurangnya hujan di daerah target. Kecepatan angin yang cukup tinggi di level 700-600 mb pada awal kegiatan mengakibatkan pertumbuhan awan di daerah target tidak berkembang dengan optimal. Dalam kondisi kelembaban rendah masih dijumpai pembentukan awan orografik di sepanjang pegunungan Bukit Barisan bagian barat DAS Waduk PLTA Kota Panjang.
\end{abstract}

Kata kunci : ENSO, pusat tekanan rendah, angin gradient, awan orografik, Waduk Kota Panjang, siklon tropis Mahasen.

\section{PENDAHULUAN}

Waduk Pembangkit Listrik Tenaga Air (PLTA) Kota Panjang di Provinsi Riau dengan kapasitas produksi listrik 114 MegaWatt merupakan PLTA yang mempunyai kontribusi cukup signifikan dalam skema pasokan listrik pada jaringan interkoneksi di wilayah Sumatra bagian tengah dan Sumatra bagian selatan.

PLTA Kota Panjang memiliki Daya terpasang sebesar $114 \mathrm{MW}$ ( $3 \times 38 \mathrm{MW}$ ) dengan memanfaatkan air sungai Kampar Kanan dan sungai Mahat yang memiliki debit rata rata air tahunan sebesar 184,4 m2/detik. PLTA Kota Panjang sangat berperan sebagai unit pembangkit energi listrik pemikul Beban (Base Load) serta daya mampu terpasang terbesar di sistem Kelistrikan Propinsi Riau. Sehingga PLTA Kota Panjang menyuplai energi listrik sebesar $40 \%$ dari total kebutuhan energi listrik bagi Propinsi Riau.

Krisis energi listrik sudah dirasakan oleh masyarakat Riau dan wilayah Sumatera Barat mulai pertengahan bulan Maret 2013. Pemadaman bergilir terpaksa dilakukan guna mengatasi krisis pasokan listrik di wilayah tersebut. Situasi seperti ini terjadi akibat Waduk Kota Panjang yang menjadi pasokan utama tenaga penggerak Pembangkit Listrik Tenaga Air (PLTA) di wilayah Sumatera Barat dan Riau semakin berkurang debitnya. Selain itu juga terjadi kerusakan di Pembangkit Listrik Tenaga Uap (PLTU) di Ombilin sebagai pemasok suplai listrik di wilayah tersebut.

Untuk mengatasi kondisi tersebut serta untuk menjaga ketersediaan air di Waduk PLTA Kota Panjang menghadapi musim kemarau tahun 2013 maka PT PLN (Persero) Pembangkitan Sumatera Bagian Utara (KIT-SBU) bekerja sama dengan Unit Pelaksana Teknis Hujan Buatan Badan Pengkajian dan Penerapan Teknologi (UPTHB-BPPT) melaksanakan kegiatan penyemaian awan melalui Teknologi Modifikasi Cuaca (TMC) di Daerah Aliran Sungai (DAS) Waduk PLTA Kota Panjang.

Variasi iklim dan cuaca di Wilayah Indonesia sangat dipengaruhi oleh sirkulasi Hadley dan Walker. Variasi curah hujan musiman di Indonesia terutama dipengaruhi oleh monsun (Ramage, 1971) dan El Nino Southern Oscillation (ENSO; Halpert and Ropelewski, 1992; Hendon 2003; Aldrian et al 2006). Faktor lain yang berpengaruh terhadap 
variasi hujan di Indonesia adalah Osilasi Madden Julian (MJO; Oh et al, 2012).

Dalam tulisan ini akan dibahas mengenai analisis cuaca pada saat pelaksaan TMC di Waduk PLTA Kota Panjang yang dilakukan pada tanggal 8 April hingga 25 Mei 2013 berdasarkan kondisi global, regional maupun lokal yang berpengaruh terhadap curah hujn di daerah target..

\section{DATA DAN METODA}

Data yang digunakan dalam tulisan ini adalah data regional serta data parameter cuaca di permukaan hasil pengukuran di sekitar lokasi penyemaian awan. Data regional berupa tekanan udara, temperatur permukaan laut, penjalaran MJO, angin gradient, serta citra satelit cuaca. Sedangkan data lokal merupakan hasil pengukuran di lokasi penyemian awan. Untuk melihat sebaran pertumbuhan awan digunakan radar cuaca.

\section{HASIL DAN PEMBAHASAN}

Kondisi cuaca selama kegiatan penerapan Teknologi Modifikasi Cuaca (TMC) dari tanggal 8 April hingga 25 Mei 2013 di DAS Waduk Kota Panjang umumnya sangat dipengaruhi oleh faktor regional dan lokal. Waduk Kota Panjang berada dalam wilayah administrasi Propinsi Riau dan Propinsi Sumatera Barat.

Fenomena regional yang cukup dominan pengaruhnya selama periode kegiatan adalah, adanya pusat tekanan rendah di Samudera Hindia sebelah barat dan sebelah selatan Sumatera, serta pengaruh MJO dari Samudera Hindia yang bergerak ke wilayah Indonesia. Selain itu cuaca di wilayah Sumatera bagian tengah juga dipengaruhi oleh munculnya beberapa Siklon Tropis di Samudera Hindia di sebelah barat, selatan dan utara Sumatera yang menyebabkan kecepatan angin yang cukup tinggi di wilayah target dan sekitarnya.

Munculnya pola pusat tekanan rendah di sekitar Sumatera dan Siklon Tropis menyebabkan sebagian besar masa udara dan awan hujan bergerak ke wilayah Utara dan Selatan Sumatera sehingga mempengaruhi keseimbangan cuaca di wilayah Sumatera bagian Barat dan Tengah. Kondisi ini menyebabkan angin di wilayah Sumatera bagian tengah sifatnya kencang dan cukup kering, sehingga menggangu proses pembentukan awan hujan di wilayah barat Riau dan Sumatera Barat. Sedangkan kondisi ENSO netral tidak terlalu banyak berpengaruh terhadap pembentukan awan hujan di Sumatera.

Selain dari faktor-faktor di atas, osilasi harian (diurnal oscillation) di daerah target juga cukup berpengaruh sehingga pembentukan awan pada sore hari dapat terjadi dengan baik. Apalagi topografi daerah target yang bergunung-gunung cukup mendukung terjadinya awan orografi.

\subsection{Analisis Cuaca Regional}

Data global/regional yang digunakan dalam menganalisis dan memprediksi kondisi cuaca di DAS Kota Panjang dan DAS Singkarak mempertimbangkan berbagai fenomena dengan berbagai skala temporal dan spasial. Pantauan ENSO (El Nino Southern Oscillation) dan MJO (Madden-Julian Oscillation) memberikan informasi mekanisme global/regional yang berpengaruh terhadap pembentukan awan di daerah target. ENSO dengan skala temporal antar-tahun mempengaruhi aktifitas keawanan global. Menurut Climate Diagnostics Bulletin - edisi Maret 2013 yang diterbitkan oleh CLIMATE PREDICTION CENTER/NCEP/NWS, sejak awal tahun 2013 ENSO netral akan terus bertahan hingga pertengahan tahun 2013.

Sementara itu, selama kegiatan penerapan TMC di Riau dan Sumatera Barat, MJO yang menunjukkan fase aktif di daerah terget yang mendukung proses pembentukan awan secara regional dengan baik muncul pada pertengahan April hingga awal Mei 2013. Sedangkan untuk melihat potensi harian, digunakan data berupa gradien wind dan citra satelit dari Bureau of Meteorology (BOM) Australia yang memberikan gambaran umum cukup baik. Untuk mendapatkan informasi keawanan secara real time, digunakan data hasil pengamatan dengan radar cuaca milik BMKG di Pekanbaru. Informasi keawanan dari radar ini sangat vital bagi jalannya kegiatan modifikasi cuaca. Data citra radar dapat memberikan informasi mengenai dimensi awan (tinggi dasar dan puncak serta diameternya) dan tingkat kepadatan awan yang menggambarkan tingkat kandungan air dalam awan.

Secara lengkap uraian hasil analisis dari setiap model parameter cuaca tersebut dapat dijelaskan sebagai berikut :

\subsubsection{ENSO}

Temperatur permukaan laut di daerah Nino 3.4 (5N-5S, 170W-120W.) yang merupakan salah satu indikatior kemunculan El Nino menunjukkanm kondisi ENSO netral. Walaupun sejak bulan Desember 2012 menunjukkan anomali SST negatif, tetapi nilainya masih dalam kisaran antara $+0.5{ }^{\circ} \mathrm{C}$ s.d $-0.5{ }^{\circ} \mathrm{C}$. Pada bulan April 2013 SST rata-ratanya adalah $27.7{ }^{\circ} \mathrm{C}$ dan anomaly $-0.1{ }^{\circ} \mathrm{C}$. Sedangkan pada bulan Mei, SST rata-ratanya menjadi $27.6{ }^{\circ} \mathrm{C}$ dan anomali $-0.3^{\circ} \mathrm{C}$. Kondisi ENSO netral seperti ini diprediksi oleh Climate Diagnostics Bulletin - edisi 
Maret 2013 akan berlangsung hingga pertengahan tahun 2013. Perubahan anomaly SST bulanan di daerah Nino 3.4 dari tahun 1994 sampai dengan Mei 2013 disajikan pada Gambar 1.

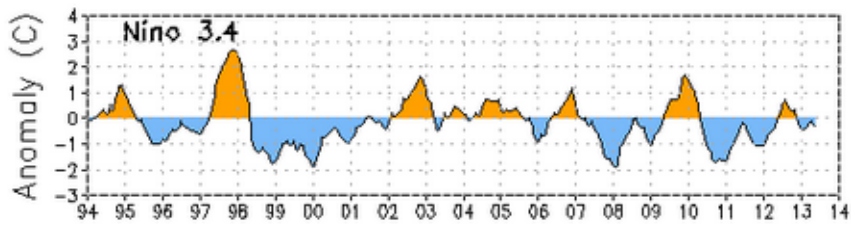

Gambar 1. Perubahan bulanan SST anomaly di daerah Nino 3.4 dari tahun 1994 s.d Mei 2013 (Climate Diagnostic Bulletin, June 2013)

Sedangkan sebaran anomaly SST pada bulan Mei 2015 di Samudra Pasifik disajikan pada Gambar 2. Pada gambar 2. terlihat bahwa nilai anomali sekitar nol terjadi di wilayah samudra pasifik bagian tengah sepanjang garis khatulistiwa.

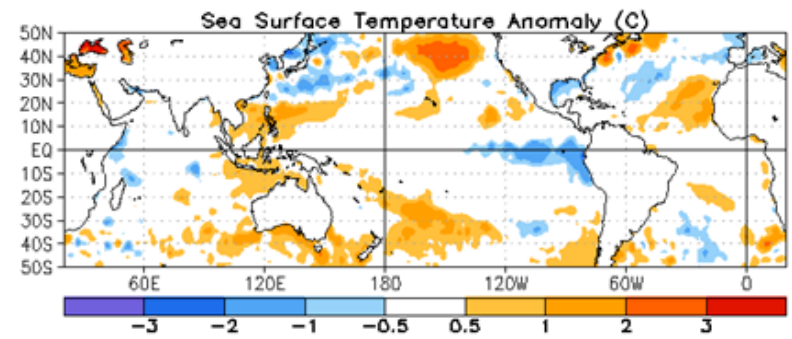

Gambar 2. Pada bulan Mei 2013, anomali SST (suhu muka laut) equator Lautan Pacific bagian tengah mendekati nilai nol. (Diambil dari Climate Diagnostics Bulletin - edisi Juni 2013).

\subsection{2. $\mathrm{MJO}$}

MJO (Madden Julian Oscillation) merupakan fenomena global berupa gelombang atmosfer di sekitar equator yang bergerak ke arah Timur. MJO mempunyai periode yang bervariasi sekitar 40 - 50 hari. Fase dari gelombang ini disebut fase aktif dan fase inaktif.

Fase terjadinya peningkatan aktifitas pertumbuhan awan diasosiasikan dengan nilai negatif dari outgoing longwave radiation (OLR) yang merupakan radiasi dari planet bumi ke luar sistem atmosfer bumi. Sebaliknya fase terjadinya aktifitas penurunan pertumbuhan awan diasosiasikan dengan nilai positif OLR. Radiasi dengan gelombang panjang dapat diserap oleh awan tebal sehingga radiasi yang keluar dari sistem atmosfer bumi menjadi negatif, sebaliknya bila awan tebal tidak banyak maka radiasi yang dipancarkan ke luar sistem atmosfer bumi akan semakin tinggi atau positif.
Penjalaran MJO yang menunjukkan aktifitas pembentukan awan di daerah equator mulai akhir tahun 2012 s.d bulan Mei 2013 disajikan pada Gambar 3. Gambar tersebut merupakan plot bujurwaktu rata-rata OLR antara 7,5 LS - 7,5 LU. Garis merah menunjukkan garis bujur lokasi Waduk PLTA Riam Kanan. Nilai positif anomali diasosiasikan dengan kurang menunjang presipitasi, sementara anomali negatif diasosiasikan dengan sangat mendukung pembentukan presipitasi.

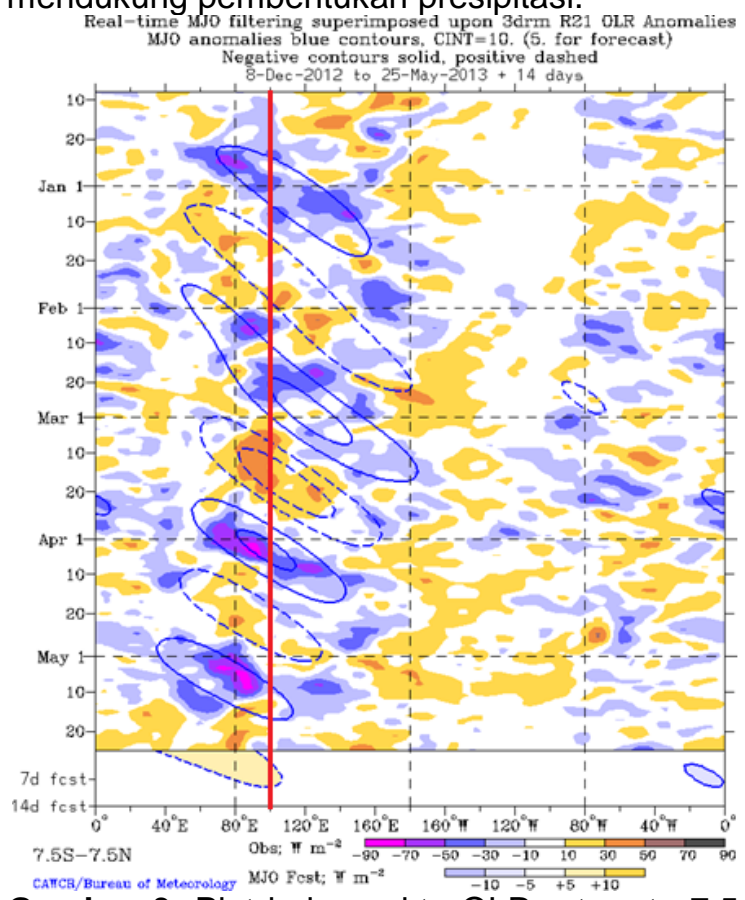

Gambar 3. Plot bujur-waktu OLR rata-rata 7,5 LS 7,5 LU. Positif anomali diasosiasikan dengan kurang mendukung presipitasi, sementara anomali negatif diasosiasikan dengan sangat mendukung pembentukan presipitasi.

Pada awal April hingga menjelang akhir bulan April 2013 terlihat terjadi peningkatan aktifitas pembentukan awan di bagian barat Indonesia. Kondisi tersebut kemudian berubah menjadi netral hingga awal Mei 2013. Selanjutnya MJO menunjukkan menigkatan aktifitas pertumbuhan awan hingg akhir Mei 2013.

\subsubsection{Angin Gradien}

Angin Gradient atau Gradient wind adalah angin pada ketinggian sekitar 1000 meter (3000 feet) di atas permukaan bumi yang menggambarkan aliran udara pada atmosfer bagian bawah dimana tidak lagi terpengaruh oleh adanya gesekan permukaan bumi. Pada level ini tidak ada pengaruh angin lokal maupun pengaruh topografi seperti angin laut, angin lembah dan sebagainya.

Angin gradien di daerah target dan sekitarnya umumnya bertiup dari arah -barat daya hingga barat laut dengan kecepatan berkisar antara 
5 - 15 knot. Pola pusat tekanan rendah yang muncul di Samudera Hindia sekitar Sumatera pada dasarian kedua bulan April serta kecepatan angin yang cukup tinggi hingga mencapai lebih dari 20 knot pada lapisan $700-600 \mathrm{mb}$ menyebabkan terganggunya sistem pembentukan awan di daerah target dan sekitarnya. Pada kurun waktu tersebut, pembentukan awan terkonsentrasi di bagian utara dan selatan Sumatera.

Beberapa Siklon Tropis yang muncul selama kegiatan TMC adalah Siklon Tropis Victoria dan Siklon Tropis Jamala di sebelah barat Daya Sumatera, serta Siklon Tropis Mahasen di utara Sumatera. Sikln Tropis Mahasen menyebabkan massa udara lembab dari Samudera tertarik menuju ke pusat siklon tersebut, akibatnya di daerah target sulit terjadi pembentukan awan hujan. Pada Gambar 4 ditunjukkan adanya beberapa pusat tekanan rendah di sekitar Sumatera yang cukup mengganggu pembentukan awan di daerah target dan sekitarnya.

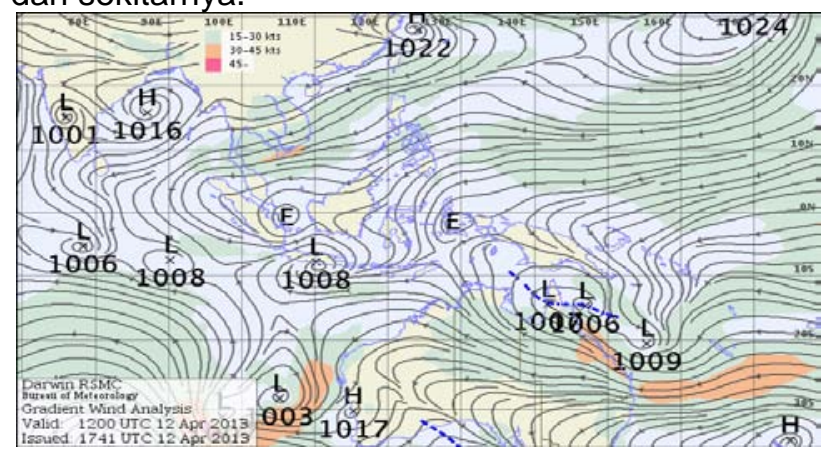

Gambar 4. Angin gradien tanggal 12 April 2013 jam 19.00 WIB (Bureau of Meteorology, Australia). Adanya beberapa pusat tekanan rendah (L) di sekitar Sumatera mengakibatkan area divergen di daerah target sehingga pembentukan awan kurang optimum.

\subsubsection{Citra Satelit}

Citra satelit merupakan informasi tutupan dan jenis awan di atmosfer seperti terlihat pada Gambar 5 berikut ini.

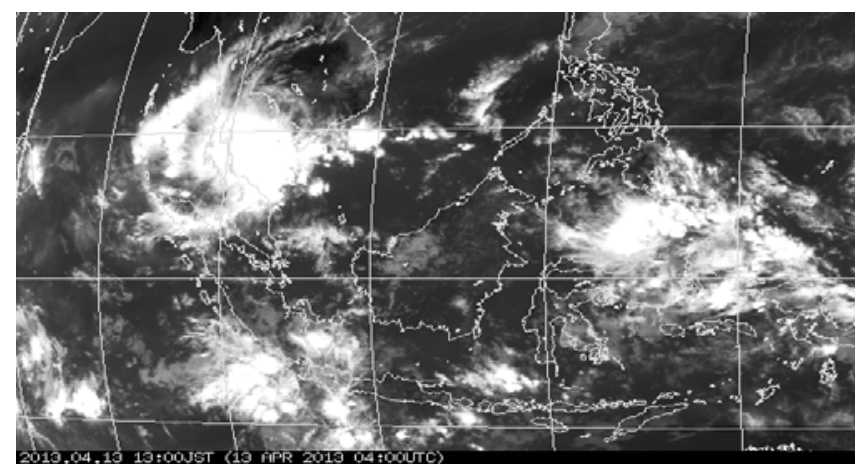

Gambar 5. Citra satelit tanggal 13 April 2013 jam 11.00 wib (Japan Meteorological Agency). Pusat pertumbuhan awan berada di Sumatera bagian utara dan Sumatera bagian selatan yang merupakan daerah pusat tekanan rendah.

Citra satelit yang digunakan untuk analisis dalam kegiatan penerapan TMC menggunakan data dari chanel infra merah yang berdasarkan suhu. Semakin dingin suhunya, warna objek semakin putih. Sebaliknya semakin panas suhunya, warna objek semakin hitam.

Munculnya pola tekanan rendah di sekitar Sumatera sangat mempengaruhi pembentukan awan hujan di DAS Kota Panjang dan DAS Singkarak. Hal ini disebabkan karena massa udara tertarik ke pusat tekanan rendah tersebut.

\subsubsection{Analisis Cuaca Lokal}

Potensi cuaca lokal dianalisa menggunakan data cuaca permukaan yang diperoleh dari pengamatan pos meteorologi (POSMET) yang berada di Muara Paiti dan Ombilin Weir. Data cuaca permukaan yang diukur terdiri dari: tekanan $(P)$; temperatur bola basah (BB) dan bola kering (BK atau T) untuk mendapatkan kelembaban udara $(\mathrm{RH})$; temperatur titik embun (Td); kecepatan angin permukaan; dan tutupan awan. Sedangkan pengukuran pilot balon (Pibal) digunakan untuk mengukur arah dan kecepatan angin di tiap level ketinggian. Selain mengukur cuaca permukaan dan angin atas, POSMET digunakan untuk memonitor perkembangan awan potensial serta suplai massa udara yang masuk ke daerah target.

Pengukuran cuaca permukaan dilakukan setiap jam dari jam 07.00 s.d. 17.00 WIB, sedangkan angin atas diukur setiap 3 jam sekali yaitu jam 07.00, 10.00, 13.00 dan 16.00 WIB. Data hasil pengukuran dan pengamatan langsung dikirim ke POSKO untuk dianalisis. Data cuaca permukaan dan angin atas hasil pengukuran ini dianalisis untuk menilai kecenderungan potensi cuaca setiap hari sehingga dapat menjadi bahan masukan dalam pelaksanaan TMC. Untuk memonitor perkembangan pertumbuhan awan di DAS Kota Panjang dan Singkarak, digunakan C-band radar yang terletak di Pekanbaru.

\subsubsection{Analisis unsur cuaca permukaan}

Unsur cuaca permukaan yang dilanalisis adalah kondisi temperatur serta kelembaban pada pengamatan pertama di pagi hari yaitu pada pukul 07.00 dan 10.00 WIB. Dari kedua unsur cuaca tersebut dapat dianalisis tentang adanya kemungkinan konvektifitas sebagai indikasi dan potensi tumbuhnya awan-awan hujan jenis cumulus serta proses orografi sebagai sumbangan kondisi lokal terhadap pertumbuhan awan hujan. Selama 
kegiatan kisaran suhu udara tersebut umumnya bervariasi untuk semua stasiun pengamatan, namun secara umum menunjukkan kenaikan antara pengamatan pertama dan kedua, dengan selisih mencapai nilai diatas $4^{\circ} \mathrm{C}$. Nilai ini mengindikasikan adanya potensi terjadinya proses konvektif.

\subsubsection{Analisis angin lapisan atas}

Disamping kondisi lokal permukaan, juga dianalisis kondisi angin atas yang bersifat lokal. Analisis angin atas ini dilakukan untuk melihat perkembangan pola angin lokal yang terbentuk. Dari analisis angin ini tampak bahwa pola angin umumnya bervariasi antara konvergen dan divergen. Kecepatan angin bervariasi antara 0-20 knot. Angin dengan kecepatan tinggi hingga mencapai lebih dari 20 knot terjadi pada awal kegiatan hingga menjelang akhir April 2013.

\subsubsection{Analisis data C-band radar}

Awan yang tumbuh di daerah target pada umumnya mulai terjadi pada siang hingga sore hari. Faktor lokal seperti angin laut juga cukup berpengaruh terhadap pertumbuhan awan di daerah target. Angin laut yang berhembus mulai pagi hingga siang hari mengakibatkan uap air naik ke atmosfer akibat tertahan oleh pegunungan yang ada di sisi barat DAS Kota Panjang seperti misalnya di Koto tinggi.

Arah angin cukup bervariasi mengikuti pola sinoptik. Pada umumnya pergerakan awan dari Barat ke Timur, sehingga awan banyak bertumpuk di batas DAS, dan puncak pertumbuhan awan di dalam DAS biasanya terjadi pada sore hari. Akan tetapi selama perioda kegiatan, arah angin berubahubah, tidak hanya angin baratan akan tetapi kadang kadang terjadi juga angin dari utara maupun dari selatan. Secara umum keberadaan awan potensial yang berada di kedua DAS berfluktuasi.

Pada awal kegiatan, tidak banyak ditemukan awan potensial yang tumbuh di dalam DAS karena kecepaatan angin yang cukup tinggi akibat adanya pusat tekanan rendah di sebelah barat daya dan utara Sumatera. Pada perioda ini awan yang sempat tumbuh tidak berkembang dengan optimal karena adanya angin dengan kecepatan tinggi pada lapisan $700-600 \mathrm{mb}$.

Setelah gangguan berupa pusat tekanan rendah dan Siklon Tropis menghilang, kondisi atmosfer di daerah target dan sekitarnya mulai ada peningkatan pertumbuhan awan. Keberadaan awan potensial yang layak untuk disemai banyak ditemui di dalam DAS maupun di daerah sekitarnya. Gambar 6. berikut ini merupakan contoh kondisi atmosfer basah pada tanggal 2 Mei 2013. Sejumlah sel awan tampak tumbuh di Utara dan di tepi Barat DAS Kota Panjang, sedangkan di DAS Singkarak juga tampak awan hujan berada di atas Danau Singkarak.

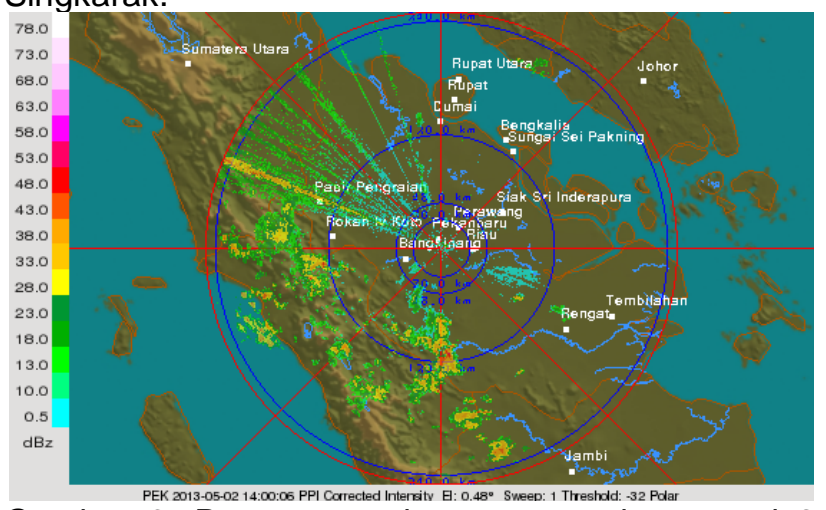

Gambar 6. Pantauan radar cuaca pada tanggal 2 Mei 2013 jam 14.00. WIB yang menunjukkan kondisi atmosfer cukup basah. Tampak awan potensial banyak ditemukan di dalam DAS Kota Panjang.

\section{KESIMPULAN}

Selama pelaksanaan TMC di DAS PLTA Kota Panjang pada tanggal 8 April hingga 25 Mei 2013 menunjukkan ENSO netral dan diperkirakan akan berlangsung sampai pertengahan tahun 2013. Sementara itu fenomena MJO fase terjadinya peningkatan aktifitas konvektif muncul pada pertengahan bulan April 2013. Dengan demikian, fenomena ENSO normal yang dipadu dengan MJO mempengaruhi kondisi cuaca di daerah target selama kegiatan TMC. Sementara itu, topografi daerah target yang merupakan daerah pegunungan mampu menghadang masa udara dan memaksanya naik ke level yang lebih tinggi sehingga memungkinkan terjadinya proses pembentukan awan. Dari kondisi cuaca yang ada dapat disimpulkan:

- Kondisi cuaca di DAS Kota Panjang dan Singkarak dipengaruhi oleh gabungan dari berbagai faktor meteorologi seperti fenomena ENSO, MJO, siklon tropis, dan faktor topografi lokal.

- Kecepatan angin yang cukup tinggi di level 700-600 mb pada awal kegiatan menngakibatkan pertumbuhan awan di daerah target tidak berkembang dengan optimal.

- $\quad$ Pada dasarian 2 bulan Mei 2013 muncul Siklon Ttropis Mahasen di utara Sumatera yang mengakibatkan masa udara tertarik ke arah siklon tresebut menyebabkan cuaca di daerah target cukup kering.

- Topografi daerah target yang bergununggunung menjadi faktor yang memungkinkan pembentukan awan meski kondisi-kondisi meteorologis lainnya cukup banyak yang menghambat. 


\section{REFERENSI}

Aldrian, E., Dümenil Gates, L., \& Widodo, F. H. (2007). Seasonal variability of indonesian rainfall in ECHAM4 simulations and in the reanalyses: The role of ENSO. Theoretical and Applied Climatology, 87(1-4), 41-59.

ENSO: Recent Evolution, Current Status and Predictions, Update prepared by: Climate Prediction Center / NCEP 15 June 2015.

Halpert MS, Ropelewski CF (1992) Temperature patterns associated with the Southern oscillation. J Climate 5: 577-593

Hendon HH (2003) Indonesian rainfall variability: Impacts of ENSO and local air-sea interaction. J Climate 16: 1775-1790.

Madden-Julian Oscillation: Recent Evolution, Current Status and Predictions, Update prepared by Climate Prediction Center I NCEP May 27, 2013.

Oh, J., Kim, K., \& Lim, G. (2012). Impact of MJO on the diurnal cycle of rainfall over the western maritime continent in the austral summer. Climate Dynamics, 38(5-6), 1167-1180.

Ramage C (1971) Monsoon meteorology. International geophysics series, vol. 15. Academic Press, 296 pp. 